\title{
A Performance do Espaço de Zoé Degani: Cenografias de Signos e Sensações, Corpos-Coisas e Acoplamentos
}

\section{*Lindsay Tarouco Gianuca}

\begin{abstract}
Resumo
O espaço cênico é um lugar-potência para diversos discursos e linguagens artísticas. A cenografia, como prática autoral no contexto espetacular, não se limita a ilustrar ou decorar; na sua incidência estética sobre a cena, pluraliza o diálogo polimórfico do evento e serve de suporte à experiência reflexiva e sensível. Apoiados sobre a prática da cenógrafa gaúcha Zoé Degani, esta proposta compreende exemplificar como sua relação com o espaço extrapola o caráter arquitetural e pictórico, invadindo outros territórios através da aderência de signos estéticos ao espaço cênico. O método de análise está apoiado na crítica genética, na investigação histórica da obra da artista e na verificação dos motivos e inquietações que originaram determinadas criações sob um caráter político inequívoco. Pretende-se aclarar o poder desta zona expressiva do espetáculo que, ao equipar o palco com engrenagens e conceitos, redimensiona o sentido das cenas e oferece novas visões sobre velhos temas. $\mathrm{O}$ espectador, ao ser confrontado com uma estética cênica incisiva, promovida pela artista, deve operar ativamente, antecipando características de um teatro pós-dramático e revivendo qualidades de um teatro brechtiano. As criações destacadas possibilitam perceber um espaço cênico que irrompe o limite do palco, faz do espectador pertencente e compartilha com ele um fato. Assim, não é o distanciamento crítico que a cenografia opera, mas a aproximação plástica entre os corpos do espaço, onde todos são vistos como peças do jogo, neste sentido, uma obra eminentemente política.
\end{abstract}

Palavras-chave: espaço cênico - Zoé Degani cenografia - acoplamento

\begin{abstract}
The theatrical space is a potential place to many discourses and artistic languages. The set design, as an authorial practice in the spectacular context, is not limited in illustration or decoration, by its aesthetical incidence over the scene, pluralize the polymorphous dialogue of the scenic event and works as support to sensible and reflexive experience. Supported on the Zoé Degani's practice to the scene, an artist who works in the south of Brazil, this propose intend to give examples of how her relation with the space goes over the architectural and pictorial character, invading the social and political territory through aesthetical signs adherence in the scenic space. The methods of analyses are based on genetic critic, historical investigation about artist's work and by checking motivations and uneasiness that originate such creations under an unmistakable politic character. The expectation is to become clear this expressive zone in the spectacle which, by equipping the stage with gears and concepts, resizes the scene meanings and offer new visions about old themes. The spectator, as being confronted with an incisive aesthetical scene, promoted by this artist, must to operate in an actively way, using post-dramatic characteristics in advanced and renewing Brech'ts theater qualities. The creations detached to analyses makes possible to observe a scenic space that goes forward the stage limits, making the spectators part of it and sharing with them the fact. So that, it's not the critic distance that scenography operates, but the plastic approach between bodies and space, where all of them are seen as pieces of the game, in this way, an eminently politic opus.
\end{abstract}

keywords: scenic space - Zoé Degani scenography - coupling

\footnotetext{
* Mestre em Artes Cênicas pela Universidade Federal do Rio Grande do Sul, professora do Curso de Teatro da Universidade Federal de Pelotas.

E-mail: lindsaygianoukas@gmail.com
} 
A presente análise verifica uma prática cenográfica que tem, na ligação que estabelece com os corpos (corpos vivos: o outro e conceituais: operações estéticas, políticas, de vida, etc.), sua destinação à cena e sua autoria simultaneamente marcada e compartilhada. Neste caso, a partir dos espaços que abrigam obras plásticas e, posteriormente, encenações, verifica-se como a obra destacada se distingue por tornar autêntica a experiência presente, suscitando os corpos, sejam eles de performers ou espectadores.

Para tanto, este artigo origina-se de uma pesquisa mais ampla registrada no documento intitulado "O Oceano Cênico de Zoé Degani: por uma cenografia plural” ${ }^{1}$ no qual a obra desta artista plástica e cenógrafa gaúcha é observada entre os anos de 1993 e 2012, compreendendo 19 anos de sua trajetória de natureza múltipla (porque ela opera nas artes plásticas, estabelece-se como artista instaladora, mas atua na performance, no vídeo, no teatro e na dança). A assinatura do artista, contudo, marca a força na obra, migra pelos campos preservando um mesmo princípio, das galerias e museus aos palcos e ruas, "a criação é a mesma e é sempre outra" (SALLES, 2009). Apesar de observar uma aderência à cena que se fortalece na cronologia estudada, conferindo a década de 90 como período em que se consolidam as instalações - pertencentes ao campo plástico; uma combustão e enfrentamento entre linguagens no final desta década e início dos anos 2000 - em que a artista como presidente da associação dos escultores do estado promove um evento para conceber "esculturas vivas", como diz, agregando a dança, o teatro de bonecos e outros gêneros no evento de artes plásticas, por exemplo; e, ao diluir-se em composições coletivas, a última década revela sua autoria inextricavelmente atrelada às encenações - seus cenários carregam toda a força conceitual que já habitava as operações chamadas "pré-cênicas" da artista e está relativizada para compor-se com os demais elementos, assim, altera irremediavelmente as composições de que participam e se cumprem neste encontro que tem sua origem e destinação nas motivações dramatúrgicas, atorais, de movimento e gesto, cênicas, enfim. Contudo, apesar da aparente migração de sua obra para o espaço cênico, as instalações da artista eram invadidas nas galerias e espaços públicos por bailarinos e atores e, como no caso de "Eternizando a Memória”, pela própria população.

Neste sentido, vê-se a variação arraigada à origem da obra, dado que a análise genética pôde revelar em processos e procedimentos registrados em anotações, croquis, fotos e rascunhos, na queda abismal que precipita ao novo, à recriação, à necessidade de desprender-se do óbvio (mesmo que o tenha por base em operações de subversão das formas, acirramento das relações, no reforço do contraste, na eliminação do clichê, etc). Mas, além do processo de criação que diz respeito à "doença do artista" ${ }^{2}$, a natureza da obra está vinculada à força que é germe e compartilha a necessidade de renovar-se, de apresentar-se ao inusitado. Trata-se de uma imprescindibilidade de relacionar-se, de promover forças a partir das imagens delineadas sempre de forma precisa no palco e fora dele, onde se nota a construção da linguagem da artista. O público, por sua vez, com frequência tomou parte das obras e era provocado ativamente como descreve a crítica a respeito da instalação de 1998:

Doze maçãs, suspensas em ganchos metálicos, tem a intenção de representar a vida, a morte e a alma. A exposição
de Zoé Degani no saguão do Centro Municipal de Cultura, "Não Existe Culpa na Semente da Maçã ", provoca o
público e, na sua simplicidade, não passa despercebida. As reações são muitas. Do olhar desconfiado e surpreso do
recepcionista do local à vontade das crianças de, ao constatar que a fruta é de verdade, tascar uma boa mordida.
Expostas desde o dia seguinte da abertura da mostra, em 12 de novembro, as maçãs já apresentam os sinais da
passagem do tempo, da vida à morte. O renascimento será representado no dia 13 de dezembro, encerramento da
exposição, quando Zoé devolverá as sementes de 50 maçãs, ofertadas pelo seu público na vernissage. (VERAS, 1998)

Esta passagem sobre a instalação da artista dá conta de verificar o apelo ao espectador, a obra como processo compartilhado, a efemeridade como tema principal. Além das maçãs, sementes e grãos compunham muitas de suas instalações. O estilo da artista está impregnado de materiais de fácil reconhecimento, extraídos do cotidiano: dos alimentos às bacias (conchas urbanas para a artista que cresceu na praia, presente em toda sua obra cênica e "pré-cênica"), de utensílios de cozinha às correntes, do sal grosso com que preenche espaços nas artes plásticas ("Eternizando a Memória", 1998) e na dança ("O Banho", 2001) às chaves, bonecas, ganchos, correntes e flores que integravam cenários e figurinos em diversos espetáculos, assim como as ataduras (especialmente utilizadas nas artes cênicas para compor as peças de Nelson Rodrigues) ou radiografias, elemento que aparta a carne do osso, entre outros, entendidos como um elenco próprio de peças. Todas essas preferências que configuram o material da obra e a consolidação de um modus operandi estarão preservados nas cria-

\footnotetext{
Dissertação de Mestrado. Orientação: Silvia Balestreri. Porto Alegre: PPGACC - IA-UFRGS, 2013.

"A arte é uma doença, é uma insatisfação humana: e o artista combate a doença fazendo mais arte, outra arte. Fazer outra arte é a única receita para a doença estética da imperfeição." (SALLES, 2009, p.33)
} 
ções cênicas, entretanto, o exposto cederá lugar ao disposto, as esculturas - agora objetos cênicos - convocarão os corpos performáticos à interação e promoverão através de inúmeros recursos (como a ampliação protética do corpo, o deboche e ironia pelas imagens formadas em conjunto, cenários que dançam e contracenam, etc.) deslocamentos e possibilidades de leituras e sensações que estarão incidindo esteticamente sobre dramaturgia, atuação, movimento, partituras, ações, etc.

Desta forma, exemplificaremos como esta obra se estabelece a partir de uma intimidade cênica com o(s) espaço(s) que em tudo se relaciona com o fazer e o pensar teatral contemporâneo, desde uma emancipação do espectador (RANCIERE, 2010), até uma relevância à efemeridade que salienta a presença e delega a todos os corpos uma qualidade cênica, desta vez através dos corpos dos objetos. A obra observada, mesmo quando não integrava uma criação coletiva como as composições cênicas, mas, de forma oposta, quando a autoria da artista era a obra inteira, o apelo do acaso, a necessidade de ressignificação pelo público, seu caráter cênico antes mesmo de estar num espaço teatral, apelava por relacionar-se, evidenciava o efêmero e apontava esta qualidade cênico-visual num devir compartilhado com o espectador, o qual era requisitado pelo próprio processo da obra como apontou a crítica destacada. Ainda a este respeito a artista confessa:

\footnotetext{
“As coisas são muito inusitadas e isso é o melhor, é o mais interessante, é quando eu consigo... [...] Que nem "nas maçãs...”: não estava combinado que a Daggi (Daggi Dornelles, bailarina e coreógrafa) ia dançar lá, ela simplesmente viu a instalação e perguntou se podia fazer uma coisa ali e eu disse: "é claro". Que é essa coisa da obra entregue, como a "sala de sal" ", isso que sempre acontece no meu trabalho e eu acho a melhor parte: é as pessoas se apropriarem e fazerem o que quiserem com a obra. Eu nunca proibi ninguém de pichar ou pegar um trabalho meu. Tanto que todas as minhas obras sempre foram roubadas, todinhas. Levavam o sal, as sementes, um pedacinho do cenário, sempre aconteceu isso..."
}

3 A obra "Eternizando a Memória" foi reintitulada pela população de "Sala de Sal". Tratava-se de uma instalação plástica por ocasiỡo da reinauguração do Mercado Público de Porto Alegre, em 1998. Material da Obra: bacias e correntes galvanizadas, sal e carvão.

O público apropriou-se da obra, elaborou um ritual para habitá-la. De forma espontânea, as pessoas retiravam os calçados para adentrar o espaço, formando uma ação performática, em que os corpos do público, inseridos à obra, originaram um corpo maior, dotado de conotação teatral, quase coreográfica. Filas se formavam com pessoas de diversas idades e classes sociais para visitar a obra, ônibus chegavam lotados vindos do interior só para conhecer o espaço transformado pela artista. Foi promovido um abaixo -assinado para que a exposição fosse permanente, o que a prorrogou por duas semanas, fato inédito no cenário nacional. 

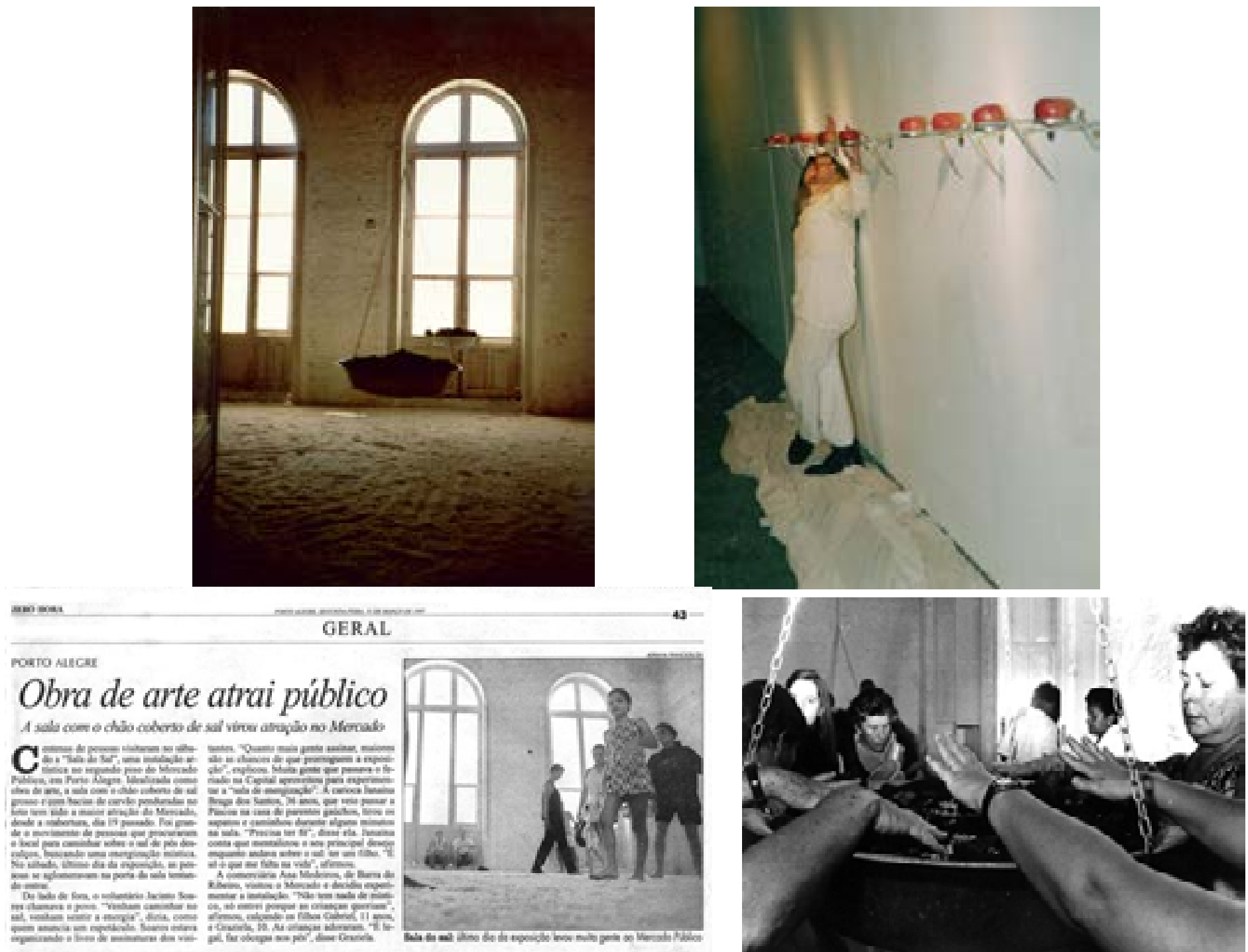

Então, se as instalações da artista já terminavam por compor-se com o público que mordia as maçãs, adotava a instalação como sala de energização popular, deitava-se na "Gema" (1995) gigante, nas artes cênicas mais acentuado ainda estará este teor relacional de sua obra. Observa-se então como a qualidade teatral escapa dos limites de sua especificidade. Pela impressão visual, o palco torna-se suporte expressivo de uma linguagem eminentemente plástica que atrai os corpos e torna-os pertencentes. Neste sentido, a relação com o espaço extrapola o caráter arquitetural, gráfico e pictórico, invade outros territórios através da aderência de signos estéticos ao espaço das encenações. Ou seja, faz-se um teatro e uma dança compondo imagens a partir do trabalho plástico sobre os espaços cênicos. Assim, a perspectiva de análise destaca um enraizamento da qualidade teatral pela inclusão indefectível dos corpos através do movimento investigativo que vai das instalações plásticas aos cenários. 


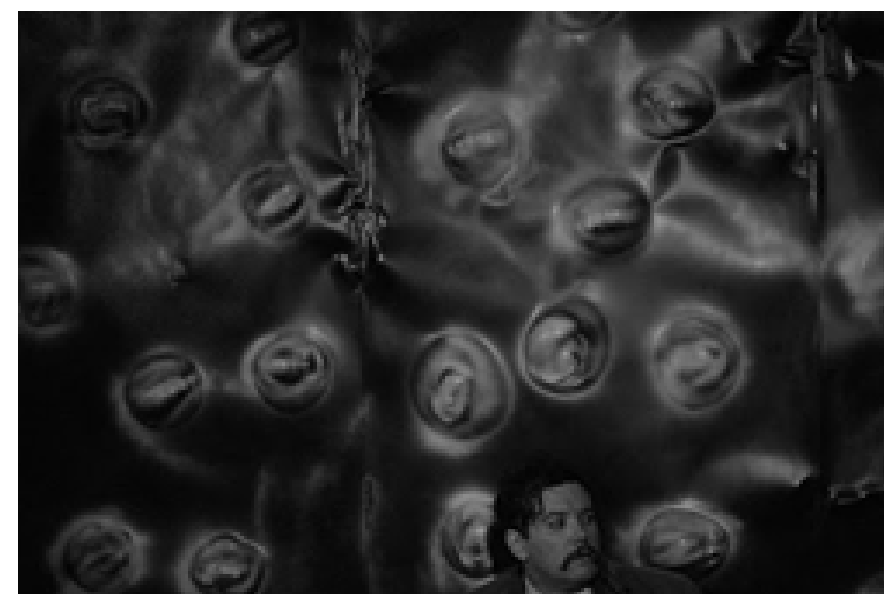

A Lição (2010) Teatro

Autor: Eugéne Ionesco

Montagem: Cia. Teatro ao Quadrado

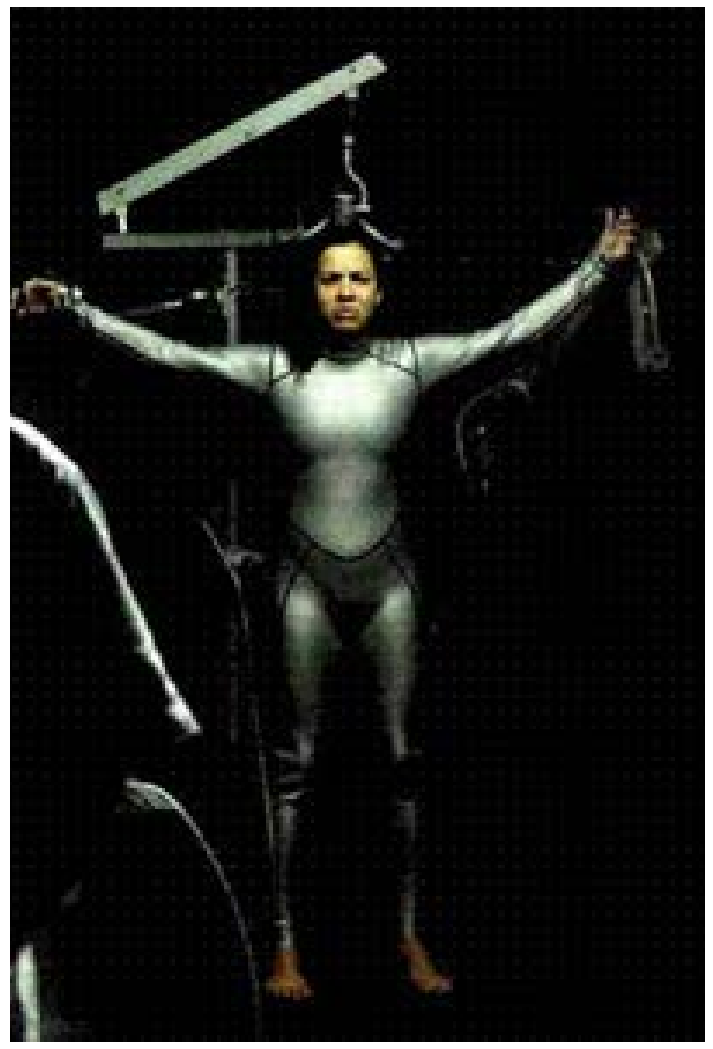

Crucial Dois Um (2007) - Teatro

Autor: Paulo Scott

Acoplamento dos corpos performático e plástico.

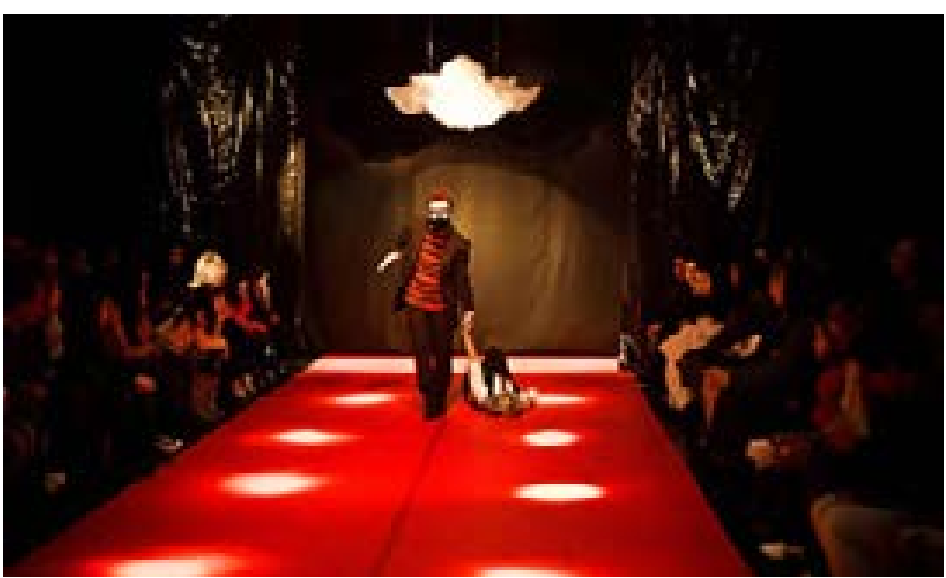

Cinderela Fashion Week (2011) - Dança

Grupo Gaia de Dança Contemporânea

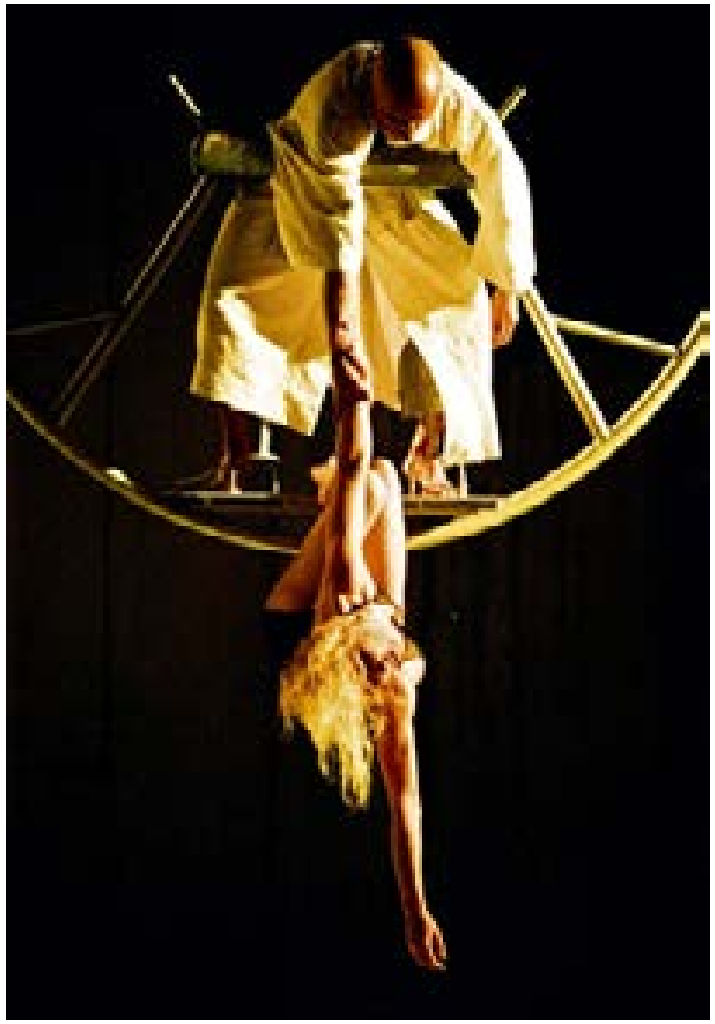

O Banho (2001) - Dança

Bailarinos e o objeto cênico que é prótese coreográfica.

Ao ilustrar algumas cenografias assinadas por Zoé Degani pretende-se realçar este caráter que marca sua autoria na cena: cenários que transubstanciam espaços através da plasticidade agregada às encenações que as pluraliza e amplifica. Por contrastar o essencial do teatro e da dança: o ator e o bailarino, a ação e o gesto, enredando-os na trama de signos estéticos introduzidos pela criação espacial, tais criações incidem atraves- 
sando a encenação, a atuação, o movimento e o corpo. Os cenários da artista não emolduram, participam, não estão restritos a delimitações de áreas ou contextualização histórica, ao contrário, promovem o desprendimento das cenas dos seus recursos operativos óbvios, instrumentaliza os corpos, desafia-os e redimensiona-os. E, se a plasticidade invade o território cênico, pode-se notar que certa teatralidade já residia na obra plástica da artista: uma intensa materialização da vivência que imprime forças irrevogáveis sobre materiais aparentemente inoperantes. Quem enxergaria o feijão, o milho, a farinha, o arroz em suas especificidades de cor e textura? A qualidade material dos recursos subversivos de Degani antecipava sua aderência à palpitação que diz respeito a um teatro vivo. O teatro da morte, por sua vez, encontra no procedimento do contraste esta "palpitante matéria cênica" (KANTOR, 2008) que diz respeito a uma teatralidade latente que habita as relações entre os corpos e coisas, na emersão da decorrência do tempo mais do que na representação ou narrativa. Assim, o teatral pertence a um abismal que se precipita no acoplamento de ilusão e realidade, morte e vida, presentação e representação, é em si e é referência a outra coisa. Não uma dicotomia, mas a coexistência edificante da qualidade teatral que se afirma por uma zona da encenação até pouco tempo escassamente investigada.

Esta zona, no presente caso, refere-se ao espaço cênico e à linguagem visual da encenação definida pela cenografia, a prática salientada para análise opera uma direção de arte da cena, define irreversivelmente as imagens, cores e formas que habitarão as encenações. Percebe-se, assim, uma busca pela autonomia da própria linguagem teatral incrustada nas operações desenvolvidas pela artista que requerem o instante, o olhar atento, que instigam a participação dos corpos e relativizam as composições. A cenografia empreendida é uma obra de arte em si, compõe-se de esculturas, de paisagens, de espaços, atmosferas, ao mesmo tempo em que se cumpre no encontro da cena, sendo esta sua destinação e origem. Assim, estas operações que atravessam irreversivelmente as encenações contemporâneas são entendidas como um desmembramento da qualidade inerente ao trabalho observado, sem saber ao certo se esta obra utiliza o teatro e a dança como suporte ou se serve de suporte às artes cênicas, já que uma vez neste campo se torna inextricavelmente pertencente a ele.

Mas, o que faz com que os espaços cênicos trabalhados pela cenógrafa se tornem extensão compartilhada das encenações e, muitas vezes, possam ser vistos como cenografias políticas? Um exemplo pontual destacado do espetáculo de dança "O Banho" (2001) ${ }^{5}$ que tem a pretensão de unir duas linguagens no desbravamento de uma terceira, dá conta de ilustrar este caráter plural que permeia toda obra da artista.
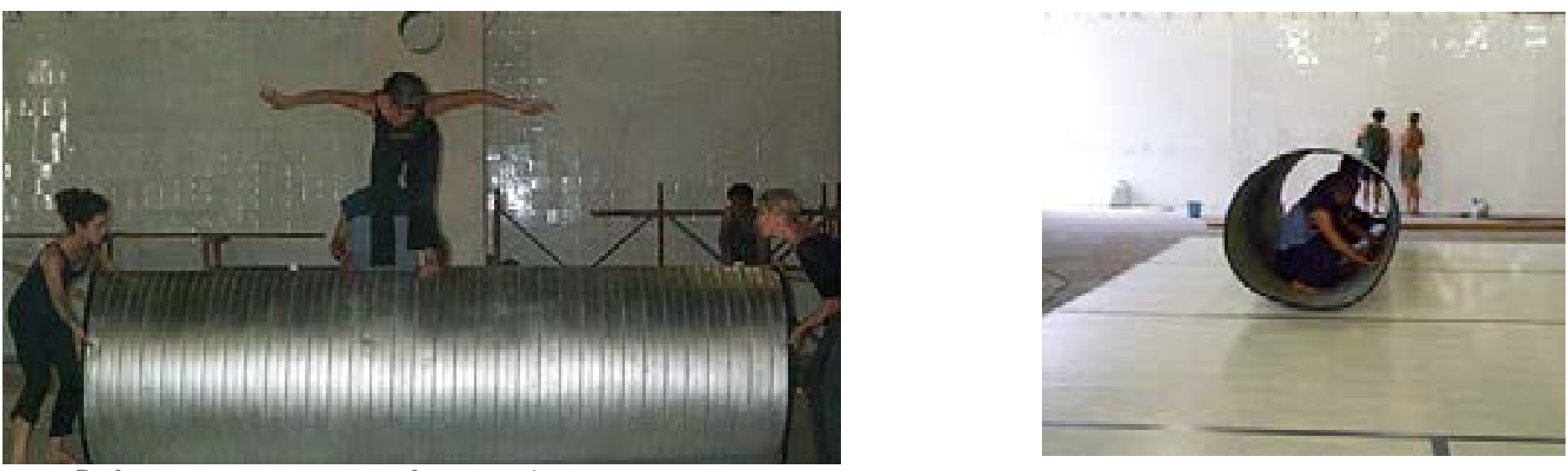

Bailarinas ensaiam com onda cenográ-

fica em "O Banho", de 2001.

O Banho vai além de um espetáculo de dança, propõe a união de dança, teatro, artes plásticas e vídeo. É um projeto idealizado a partir da pesquisa e investigação da artista plástica Zoé Degani sobre a água como bem finito [...] É um projeto de séria investigação do movimento, unindo dança e artes plásticas, em busca de uma nova forma de se mostrar a cena teatral. Trecho extraído do texto de apresentação do espetáculo. ${ }^{6}$

\footnotetext{
5 Este trabalho é um exemplo de obra plural. A séria de instalações "O Banho" habitou diversas galerias e espaços em Porto Alegre e São Paulo entre 1997 e 2000. Quando a artista convidou a Cia. Terpsi para realizar o espetóculo de mesmo nome, numa necessidade de expansão da própria obra e linguagem, de variação intrínseca à concepção artística. O resultado deu origem ao espetáculo que agregava instalação, dança, vídeo na composição cênica.

6 Trecho extraído do texto de apresentação do espetáculo.
} 
No galpão de 1000 metros quadrados, em que a artista se dedicou pelo período de um ano a transformá-lo em espaço cênico, um objeto presta-se a exemplificar a "bidimensionalidade característica e constitutiva do teatro" (DE MARINIS, 1997), além da presentificação do fato, catalisando uma experiência sensível e, em seguida, firmando-se como posição política ao compartilhar a destinação comum a todos os seres vivos: a morte. Eis, o duto que é onda, movimento, forma, lixo. É objeto cênico e objeto autêntico. A mesma onda que é surfada em cilindro pelas bailarinas, noutro momento cruza o palco suspensa, o corpo do objeto "se presta" ao sentido pela forma, mas é também a presentificação dos dutos secos de uma civilização sem água, um signo que além da referência, da remissão ao sentido, é violência, não designa, ultrapassa a leitura, requer decifração. $O$ duto seco é a sentença fatídica de uma civilização sem água, o objeto é simplesmente, apesar de servir às interações com os corpos, ou melhor, requerê-las, especialmente em se tratando de um espetáculo de dança.

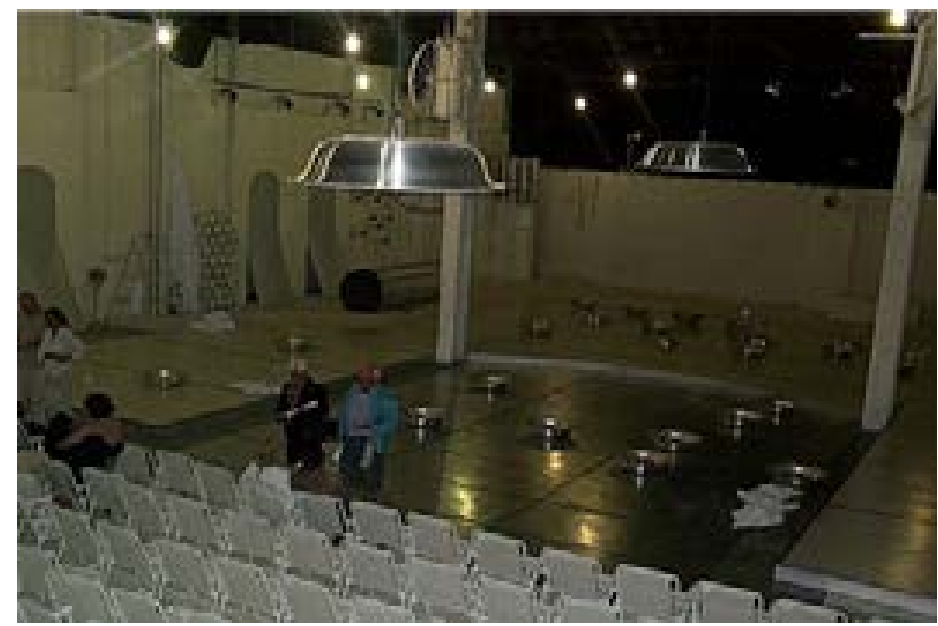

Bailarinas ensaiam com onda cenográfica em "O Banho", de 2001.

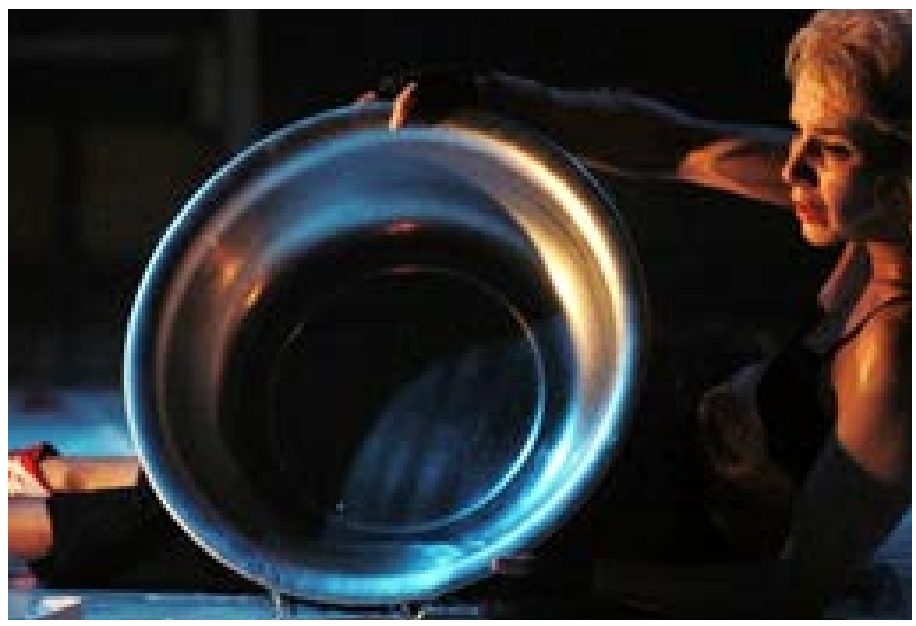

Bailarina dança com inúmeros corposbacias da obra de Degani.

Ora, e se de um lado o objeto preserva sua autonomia, não representando ser outra coisa senão ele mesmo, de outro se presta à metáfora, está em cena para jogar com os performers, só o encontro do corpo do objeto ao corpo performático exigindo a este último um atletismo para relacionar-se, poderá multiplicar as derivações que imagem provocada e embate corpo a corpo sustentam e promovem na cena. O objeto requer dos corpos dos bailarinos o movimento, extrai do caráter representativo a ação autêntica, faz surgir a figura, a condição humana, o atletismo físico ante à representação. A bacia é objeto e é concha, é lembrança de banhar-se no árido e asséptico espaço que não conta com uma gota de água, mas com toneladas de sal grosso (trazendo a sensação de secura de uma civilização sem água como sensação real compartilhada no espaço, não como representação de uma ilusão). O que a análise sobre o "grande projeto" (SALLES, 2009) de 19 anos (suprimido pela natureza deste artigo) da artista torna possível perceber é o quanto o caráter autoral de sua obra está também no referido teor relacional de seu trabalho e é por isso que efetivasse na encenação com muita força, sendo os espaços manipulados pela sua cenografia multiplicadores dos próprios estados e princípios das artes cênicas: a presença, o compartilhamento de um fato em comum, a saliência do efêmero. Assim, pode-se afirmar que se o trabalho plástico da artista possuía um teor de teatralidade pela atração dos corpos às obras, no teatro e na dança, a plasticidade estará infiltrada nas encenações, o que reforça a natureza das linguagens ao mesmo tempo em que, pela sua distinção e acoplamento, nutrem-se de sua própria materialidade reciprocamente.

A obra, ao deixar de ser escultura para assumir o papel de objeto cênico, ou espaço de representação em prol da criação de um espaço de experiência, catalisa a sensação de contágio descrita por Antonin Artaud (1999) como a matéria singular do exercício teatral. Colocam-se perante o espectador obras que deslocam, decompõem, estranham e interpõem o inusitado, assim, promovem a queda, a sensação (DELEUZE, 2007); no campo criado entre artista e público se assenta o poder germinativo da performance, nesta perspectiva, uma 
performance espacial, o que Kantor (2008) chamou da "encenação da sala". Os espaços, assim, tornam-se multiplicadores dos sentidos e sensações do texto, do movimento, dos estados de presença, etc. A cenografia firma-se como extensão do princípio teatral, ignorando uma herança decorativa, ilustrativa ou funcional, resgata o caráter maquínico da cena, reforça o jogo próprio do teatro, reinaugura estados, compartilha possibilidades. A obra destacada marca-se por uma natureza acopladora que, ao legitimar todas as vivências e leituras, pluraliza os encontros, as possibilidades e, ao inserir-se à cena contemporânea, acentua as possibilidades das operações cenográficas e reitera a condição de presentificação.

Têm-se, portanto, mesmo que de forma abreviada, algumas circunstâncias que exemplificam as relações migratórias que se delinearam na trajetória da artista: compondo esculturas, espaços, cenários, criando imagens para habitar as cenas, sua obra marca-se pela relação íntima que estabelece entre as peças plásticas e os corpos cênicos, o espectador, por sua vez, é constantemente convocado a participar, decidir, redigir seu próprio texto cênico, ou melhor, compartilhar a experiência sensível que o torna integrante, pertencente, co-autor, etc., já que caberá a cada um decifrar o duto que dança, a bailarina que surfa, o signo que está disposto na encenação recuperando a origem da peça e promovendo relações que o redefinem.

Esta obra de traços acopladores e operações agregadoras permite perceber o poder desta zona da encenação (a cenografia) como campo de exploração fértil para as relações cênicas. Pela necessidade do outro como dado inerente à obra, não será então o distanciamento crítico, mas a aproximação plástica entre os corpos e o espaço, onde todos são vistos como peças do jogo, que a cenografia operará.

Ao permitir as experiências singulares, incita um posicionamento frente ao fato dado, a cenografia de Degani torna-se parcela da obra cênica e a redefine. Ou seja, na ampliação do diálogo polimórfico do evento, o signo cênico implicará uma posição, convocará o espectador, ingressará na ação do ator e no movimento do bailarino, abandonando seu status de superfície, de espaço circundante, a cenografia que invade o campo de atuação, coreográfico, dramatúrgico, etc. instala também uma nova ordem política sobre a cena e desta com seu receptor, especialmente se considerarmos "o político redefinido como ações dentro de um campo de poder," como aponta Jorge Dubatti, "o político como procedimento" 7 . Procedimento este que trata da saliência à efemeridade, do compartilhamento da experiência estética, da subversão dos clichês, da saturação do átomo (DELEUZE; GUATTARI, 1992). A condensação de um texto em formas plásticas, de um estado de presença em relações pluralizadas, resgata os valores do teatro épico e antecipa dados da condição pós-dramática (LEHMANN, 2007), especialmente se considerarmos as referentes à construção de um teatro da imagem, ao desafio do corpo performático e à experiência compartilhada que exige a presença espectatorial na redação de seu texto espetacular e na ação transformadora sobre as coisas do mundo. A cenografia observada, portanto, trata no microcosmo da encenação do macrocosmo de nossas relações de poder, questiona o lugar das coisas e sua posição imposta, os universos pluralizados pelos cenários da artista multiplicam e autorizam novas formas de experiência. São cenários que atravessam as encenações e são atravessados pelas relações dos corpos e, na composição coletiva, espaços cênicos estendidos, obra que suscita a sensação para promover novas reações e vivências sobre os fatos dados.

Ainda, esta vivência requerida origina-se de um acoplamento entre obra e vida de forma inextricável. O processo criativo e as concepções plásticas e cênicas de Degani estão impregnados de suas experiências vividas. O fato de ter sido atleta, por exemplo, lhe instrumentalizou a desenvolver profundamente as relações entre peso, variação de velocidade, tempo cronológico e tempo sensação. Da mesma forma, sua experiência como motociclista vivida por mais de 30 anos lhe rendeu uma compreensão ímpar sobre a investigação entre corpo e objeto/máquina. $\mathrm{O}$ atletismo neste estudo está tanto nas operações cenográficas observadas, um atletismo físico requerido pelos objetos cênicos, como também um atletismo conceitual, fruto da análise, que requer esforço para compreender a multiplicidade das origens e consequências de processo e obra.

Exemplo disso são as relações entre movimento e forma, muito presentes no trabalho de Zoé Degani, que se desenvolveram a partir de sua experiência como atleta ${ }^{8}$, em investigações sobre a qualidade de movimento, o risco, a velocidade, juntamente com suas experiências plásticas de forma, cor, textura, peso, leveza, etc. O destaque atribuído a estas relações merece um olhar atento sobre o desdobramento de sua operação. Alheios à palavra, a sintonia entre movimento, variação de velocidades e formas (geométricas ou não) parece

\footnotetext{
$7 \quad$ Palestra proferida no VII Colóquio de Artes Cênicas na Iberoamerica. Montevideo, 7 de dezembro de 2012.

Entre 1976 e meados de 1982 a artista executava seus trabalhos plásticos em segundo plano. Sua prática no atletismo, sendo esta sua principal ocupação à época, lhe rendeu diversas medalhas como velocista. Ministrou ainda aulas de educação física em escolas regulares e na APAE (Associação dos Pais e Amigos dos Excepcionais) para turmas de pessoas portadoras de necessidades especiais, o que lhe permitiu observar os corpos desafiando seus limites e as relações apontadas: peso, velocidade, qualidade de movimento, etc.
} 
conter uma" "pré-existência" cênica que é a matéria-prima da cena" (KANTOR, 2008, p. 139). Neste sentido, verifica-se uma expressão intrínseca ao mostrar-se: o encontro com o outro (o público), que é anterior a qualquer relação dramatúrgica. Aqui diz respeito ao acoplamento poético das coisas com os corpos.

Um dos mecanismos frequentes na obra cenográfica de Zoé Degani é a inserção de peças, esculturas, objetos que interferirão diretamente nos movimentos dos corpos cênicos. Antonin Artaud, ao falar de um "atletismo afetivo" que se desprenderá da língua para criação de um estado intenso dos corpos, indica aos atores como operar na dobra, no abismo e na crueldade que definirão seu teatro ${ }^{9}$; Gilles Deleuze, por sua vez, aponta um atletismo filosófico no batismo de conceitos ao observar a natureza da filosofia (1992, p.16) e, ao voltar-se para a pintura de Francis Bacon, notará o atletismo que marca figuras atléticas percorridas por um movimento intenso, que remeterá a "imagem real ao corpo" (2007). Ora, o atletismo diz respeito diretamente aos corpos: dos atores em Artaud, corpos filosóficos e personagens conceituais em Deleuze, corpos-figuras (carne) em Bacon. Nesta outra natureza, o cenário, que não diz respeito a um estado do ator, tampouco à filosofia ou à pintura, são as esculturas necessariamente vinculadas aos corpos dos atores e bailarinos que desencadearão um atletismo intenso, primeiramente pela forma que exigirá uma reação imediata, de deformação, acoplamento e, em seguida, pela relação que estabelecerá na cena, jogando com a anatomia requerida na sua mobilidade, no jogo, no corpo a corpo resultado do confronto entre a materialidade do objeto e a maleabilidade dos corpos.

\footnotetext{
Tu és a continuidade do teu equipamento. Quando eu corria, não existia diferença entre o meu corpo e o sapato de prego $^{10}$ [...] tu estás aderido ao equipamento, um corredor de fórmula 1, ele se torna o carro, ele e a máquina são um corpo só, não tem como separar a ação da ferramenta. Por isso é tão importante a tinta certa para pintar, ou a ferramenta certa para construir.
}

Inspirados pela colocação da artista, observar algumas peças que insere em determinados espetáculos promovendo uma adequação, uma pluralização, uma morfogenia dos corpos que destinará a cena a um campo de passagens, na combustão da força-peça à força-corpo, elucida um método. Embora a artista alegue que não existe método (receita, neste sentido), a recorrência de determinados elementos e operações propostos a partir de seu trabalho na cena distinguem esta aproximação via atletismo. Na exterioridade da epiderme, da forma sem conteúdo, puramente forma que, agregadas aos corpos, intensificam o jogo, preservam a encenação na superfície, fugindo de um psicologismo, mas aliando o real e a ilusão, borrando os limites, já que denuncia aos olhos do público uma verdade visual legítima, ao mesmo tempo em que exige dos performers a fuga do seu automatismo, pois a máquina-equipamento, o objeto cênico está aderido a um corpo necessariamente em fluxo. Então, o cenário aparece com a função de interferir no trabalho do ator, ele existe porque e com este encontro, e o ator, a partir desta convergência, performará no acoplamento, na carne, no atletismo. "Tornar-se "ator" significa, portanto, ser capaz de "agir", ou seja, libertar-se das reatividades e dos automatismos profundamente enraizados no organismo, realizando-se assim uma verdadeira revolução fisiológica.” (QUILICY sobre Artaud, Sala Preta, 2011, p. 99)

Estas peças inauguram uma nova ordem de poder na cena, são definitivas, o corpo será exigido além da sua capacidade de interpretação ou representação, é um corpo componente. As esculturas, assim na cena, antecipam a situação, é ela que interessa mais do que os personagens. Ao catalisar a situação, a máquina que se cumpre com o corpo risca a cena. O professor da "Lição" de Ionesco, por exemplo, passa a ser mais um dado visual do jogo, já que a tortura está na peça que exige a atriz, na cadeira de estudos que range os ferros como um balanço de parque, nas armadilhas que extirparão a atriz.

\footnotetext{
9 Sobre os equívocos na interpretação do teatro da crueldade ver Quilicy, Cassiano Sydow. Antonin Ärtaud: o ator e a física dos afetos. Disponível em: http://www.revistasalapreta.com.br/index.php/salapreta/article/viewFile/101/99 Acessado em 10/02/2013 10 Tênis especial para velocista.
} 


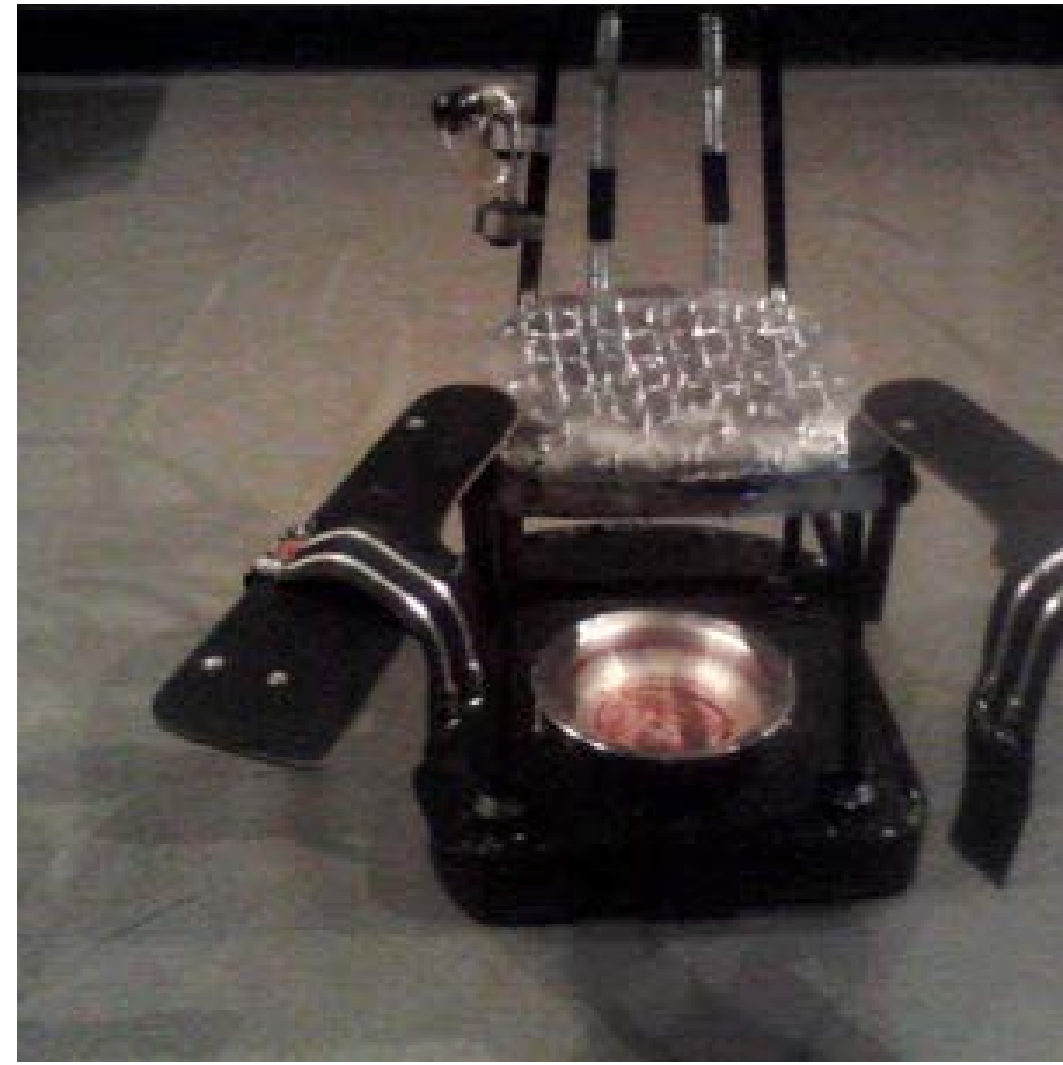

A cadeira de "A Lição". Objeto feito a partir de uma cadeira de estudos cujo braço de apoio transformouse em armadilhas móveis para as pernas, o assento em madeira e borracha simulava uma chapa com pontas metálicas. Tubos de silicone, velcros, zíperes, coleira e algemas também compunham a máquina de tortura.

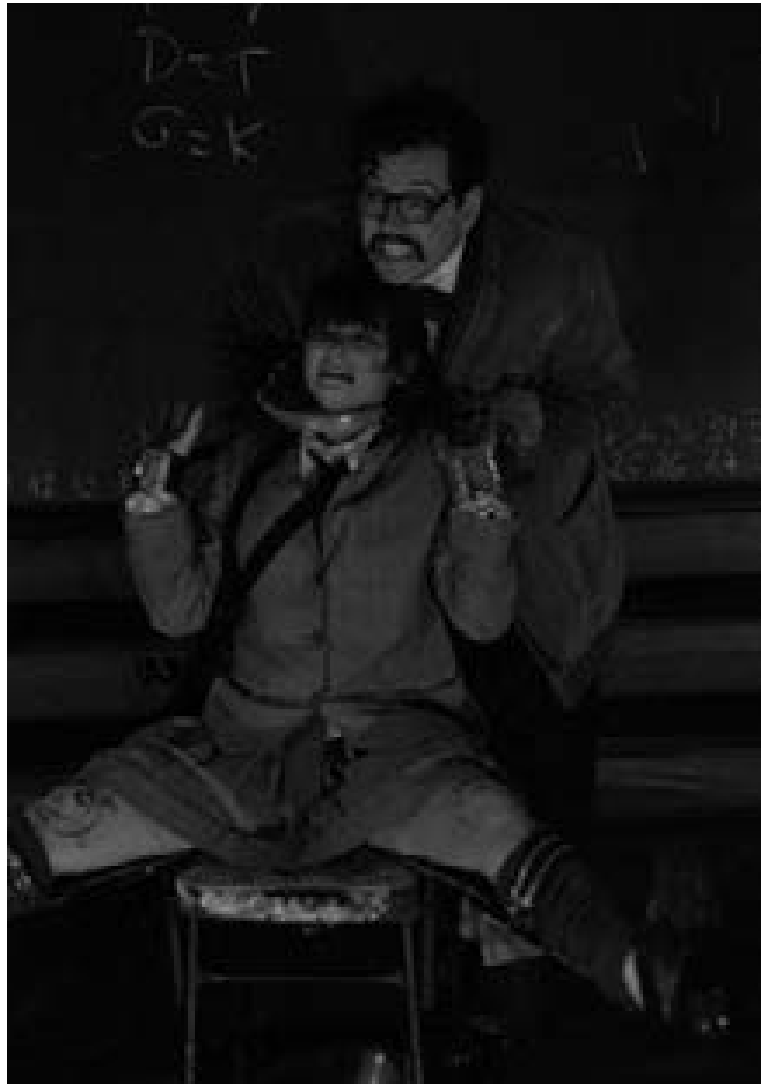

Marcelo Adams e Luiza Herter em "A Lição", a atriz e a cadeira configuram uma única ação.

O crítico teatral Renato Mendonça narra entre "as sete melhores cenas do teatro gaúcho em 2010":

Comigo é assim: à medida que o tempo passa, o todo da encenação vai se esvanecendo, mas restam brilhantes e inesqueciveis algumas cenas, aquelas que realmente me tocaram. [...] O sangue que escorre da cadeira em que o professor Marcelo Adams brutaliza a aluna Luisa Herter é o coroamento de uma jornada ao longo da incomunicabilidade, da violência e da opressão. Muito além da discussão sobre a maneira como a diretora Margarida Leoni Peixoto releu o texto de Eugène Ionesco "A Lição”, essa imagem (e o som do líquido escorrendo) representou o mal absoluto e inútil.

Como descrito, além do apelo visual, a bacia estrategicamente posicionada abaixo da cadeira (cujo assento possuía um artefato não aparente com sangue falso e, no assassinato da aluna, rompido, deixa vazar o sangue para a bacia) funciona como um amplificador do som sutil do gotejar que permanecerá pingando até o fim do espetáculo e mesmo após os agradecimentos e a saída do público. O objeto, desta vez, resolve a cena final, sintetiza a crueldade, a composição traz a inocência no som do balanço (pelo ranger dos ferros), a situação na cadeira da sala de aula que é o objeto de tortura que crava, que atravessa, que oprime; a ideia do sangue, que partiu da direção na intenção de jorrar litros de sangue do teto (o qual a artista repudiou pela sujeira e transtorno que provocaria), aparece delicadamente posicionado na escultura que reforça a crueldade e pertence à infância, no cenário que se insere no elenco. A cadeira como figura do horror aparece nas palavras do drama- 
turgo Ivo Bender:

O final da peça, com a aluna presa àquela cadeira (de ginecologista?) ultrapassa a brutalidade e atinge o nivel do horror absoluto. E o sangue a gotejar na bacia remete de imediato à mais espantosa escatologia do horror. O clímax da peça que ocorre na matança da aluna acaba, então, por se perpetuar na cena e o ruído do gotejar apenas acentua o diabolismo da encenação.

O objeto assim, além de invadir a atuação, está na cena operando sobre sua visualidade e sonoridade, o objeto amplifica as áreas que não lhe pertencem e reitera a função que lhe é própria, redignifica a cenografia como criação que atravessa, muito além do adorno. O objeto traz em si a condensação, a saturação do átomo, traz à tona a situação, antes das representações.

Esta última parece mesmo ser a condição principal desta obra: arrancar o presente de toda representação. É por isso que seu trabalho contamina e é contaminado, se expõe à variação contínua. Está impregnado de vida, nesta perspectiva é possível compreender a afirmação da artista que diz que

\footnotetext{
não existe obra sem vida. As pessoas às vezes me chamam para dar cursos de cenografia, de artes plásticas, mas eu não tenho como ensinar a criar uma obra. Eu posso ensinar como se fura uma parede, mas para haver obra tem que haver vida, não existe receita de como ser um artista, pois é a vida que te faz um artista, quando fazes obra dela.
}

Assim, compondo-se de espaços sensíveis, de acoplamentos em múltiplas instâncias, de objetos simultaneamente autônomos e que requerem ações pelo contexto relacional em que se inserem é que se acredita que a cenografia observada é tão efetiva: porque resgata, por uma zona periférica da encenação - além do texto, do ator, do gesto - sua condição presente. Não há representação, mas relação, o teatro reforça-se na sua condição de jogo presente, prestando-se às contradições, ambiguidades e multiplicidade através da cenografia que atravessa ação e texto, gesto e movimento, som e iluminação, etc. A condição cênica de compartilhamento de experiência presente é exercida por esta obra plural, de signos sensíveis, objetos-cenas, operando nos espaços a saliência da vida que antecipa uma emancipação em múltiplos aspectos: da cena à ação, da imagem ao objeto, do performer ao espectador.

Portanto, quando se permite irromper as fronteiras da especificidade das linguagens a fim de compreendê-las na sua complementaridade, a teatralidade está expandida e pode ser redefinida. O teatral aqui se manifesta pela qualidade do acoplamento, da sobreposição de linguagens e práticas, nos procedimentos pouco convencionais que ressaltam a efemeridade na obra de Zoé Degani. E, se a qualidade efêmera das artes cênicas é um dos seus pilares, na soma de linguagens em prol de um objetivo em comum, a cena contemporânea, não somente fortalece suas qualidades intrínsecas como reitera seu território híbrido e multíplice. O espaço, desta vez, é atuante, exerce uma performatividade incisiva, é capaz não somente de abrigar, mas de redirecionar e redimensionar as encenações. Zoé Degani assina cenografias repletas de signos, passíveis de leitura semiológica, mas que promovem antes as sensações. Seus corpos-coisas pluralizam os elencos, atravessam os movimentos, sua obra acopladora encontrou sua destinação quando, nas artes cênicas, cumpre-se plural e infinitamente variando-se. Por fim, não se tratam de um cadeiras de tortura, ondas-dutos, maçãs cujas sementes não têm culpa ou salas e espetáculos revestidos de sal, mas de uma obra que tem o poder de conferir o presente-sensação à toda representação-sentido. 


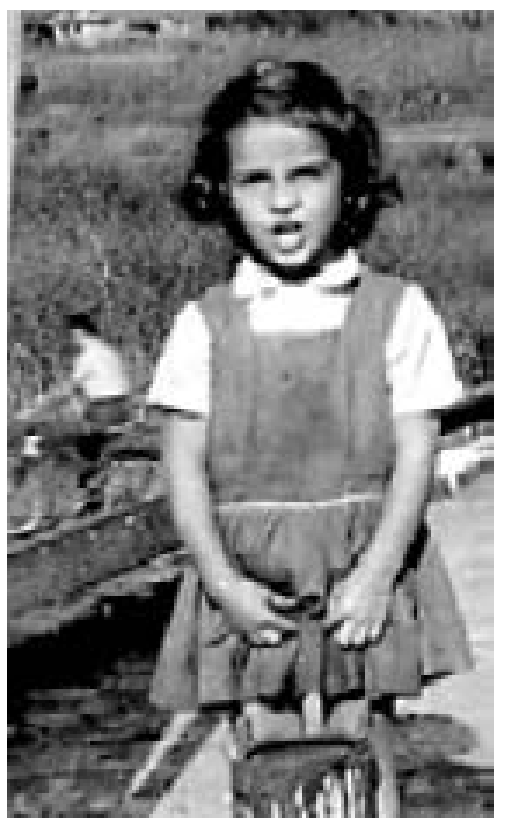

Zoé Degani em 1961 já desenvolvia sua habilidade com os materiais.

Na foto, com uma lata de tintas acompanhava o pai na construção da casa da família: o acoplamento de Vida e Obra definem a linguagem cenográfica da artista.

\section{Referências}

ARTAUD, Antonin. O Teatro e seu Duplo. São Paulo: Martins Fontes, 1999.

DELEUZE, Gilles.Francis Bacon: Lógica da Sensação. Rio de Janeiro: Jorge Zahar, 2007. .Proust e os Signos. Ed. Forense Universitária, Rio de Janeiro, 2003.

DELEUZE, Gilles; GUATTARI, Félix. O que é filosofia? Rio de Janeiro: Ed. 34, 1992. ; __ . Mil Platôs - Capitalismo e Esquizofrenia. vol 3. São Paulo: Ed. 34, 1997.

GIANUCA, Lindsay. O Oceano Cênico de Zoé Degani: por uma cenografia plural. Dissertação de Mestrado. Orientação: Silvia Balestreri Nunes. Porto Alegre: PPGAC - IA-UFRGS, 2013.

KANTOR, Tadeusz. O Teatro da Morte. São Paulo: Perspectiva, 2008.

LEHMANN, Hans-Thies. Teatro Pós-dramático. São Paulo: Cosac Naify, 2007.

DE MARINIS, Marco. Comprender el teatro - Lineamientos de una nueva teatrología. Buenos Aires: Galerna,1997.

RANCIÈRE, Jacques. El espectador emancipado. Buenos Aires: Manantial, 2010

SALLES, Cecília Almeida. Gesto Inacabado: processo de criação artística. São Paulo: Annablume, 2009. VERAS, Eduardo. Maçã Inocente. In: Zero Hora. Porto Alegre, 25 de novembro de 1998.

*Imagens cedidas pela artista: acervo 